\title{
Plasma-enhanced chemical vapor deposition of
}

\section{intrinsic microcrystalline silicon from chlorine-containing source gas}

\author{
R. Platz and S. Wagner
}

Princeton University, Department of Electrical Engineering, Princeton NJ 08544, USA

\begin{abstract}
Microcrystalline silicon $(\mu \mathrm{c}-\mathrm{Si}: \mathrm{H})$ of truly intrinsic character can be deposited by plasmaenhanced chemical vapor deposition (PECVD) when dichlorosilane $\left(\mathrm{SiH}_{2} \mathrm{Cl}_{2}\right)$ is added to the $\mathrm{SiH}_{4}-\mathrm{H}_{2}$ source gas. A dark-conductivity of $5 \cdot 10^{-8} \mathrm{~S} / \mathrm{cm}$, activation energy of $0.62 \mathrm{eV}$ and photoconductivity of $1 \cdot 10^{-5} \mathrm{~S} / \mathrm{cm}$ are obtained. The optical bandgap for this material is approximately $1.1 \mathrm{eV}$. No special gas purification or microdoping is required. $\mathrm{SiH}_{2} \mathrm{Cl}_{2}$ added in small amounts has the additional effects of enhancing the crystallinity, and of reducing the oxygen incorporation by over a factor of two. Sub-bandgap absorption spectroscopy indicates a low defect density. VHF deposition yields material with lower defect density and higher photo-conductivity than material deposited using DC plasma excitation. Transition from amorphous to microcrystalline growth occurs during the first $100-150 \mathrm{~nm}$ of film growth. The oxygen content increases as the crystallinity increases. A first p-i-n solar cell with a $1.8 \mu \mathrm{m}$ thick $\mu \mathrm{c}-\mathrm{Si}: \mathrm{H}(: \mathrm{Cl})$ i-layer exhibits $\mathrm{V}_{\mathrm{oc}}=0.35 \mathrm{~V}, \mathrm{I}_{\mathrm{sc}}=4.14 \mathrm{~mA} / \mathrm{cm}^{2}$ and $\mathrm{FF}=55 \%$, demonstrating device-quality material.
\end{abstract}




\section{Introduction}

Microcrystalline silicon $(\mu \mathrm{c}-\mathrm{Si}: \mathrm{H})$ is a form of thin-film silicon which is of growing interest for device applications. P-i-n solar cells incorporating $\mu \mathrm{c}-\mathrm{Si}: \mathrm{H}$ as the absorbing layer produce high photo-current and are stable against light-soaking ${ }^{1-3}$. Thin-film transistors (TFTs) with $\mu \mathrm{c}-\mathrm{Si}: \mathrm{H}$ channel layers have higher on-currents than amorphous silicon TFTs ${ }^{4-6}$.

$\mu \mathrm{c}-\mathrm{Si}: \mathrm{H}$ is deposited at substrate temperatures of $200-300^{\circ} \mathrm{C}$ from highly $\mathrm{H}_{2}$ diluted silane $\left(\mathrm{SiH}_{4}\right)$ by PECVD. Because of oxygen contamination ${ }^{7,8} \mu \mathrm{c}-\mathrm{Si}: \mathrm{H}$ is strongly n-type when deposited without special precautions. These donors reduce the electric field in part of the i-layer in a solar cell and thereby reduce the photocurrent collection efficiency. In a TFT, the unwanted oxygen doping causes undesirably high off-currents.

The oxygen donors can be compensated with boron at the ppm level ("microdoping"1,9,10). The need to tailor the boron doping to the case-by-case oxygen contamination and to control the doping within a very narrow window renders this method unsuitable for industrial practice. Truly intrinsic $\mu \mathrm{c}-\mathrm{Si}: \mathrm{H}$ has been obtained recently by purifying the gas with an oxygen getter and by carefully controlling the reactor condition ${ }^{8}$. A more robust deposition process which does not require additional equipment would be desirable for the production of $\mu \mathrm{c}-\mathrm{Si}: \mathrm{H}$ on an industrial scale.

In the present paper, we present a method for obtaining device-grade $\mu \mathrm{c}-\mathrm{Si}: \mathrm{H}$ by PECVD from $\mathrm{SiH}_{4}$ and $\mathrm{SiH}_{2} \mathrm{Cl}_{2}$ diluted in $\mathrm{H}_{2}$. Intrinsic material is deposited without any further measure and the growth process is very tolerant to changes in reactor conditions. Microcrystalline silicon using $\mathrm{SiH}_{2} \mathrm{Cl}_{2}$ as a precursor gas has been deposited at several laboratories ${ }^{11-13}$, however without focussing on intrinsic material suitable for device-applications. 


\section{Experiment}

All samples were deposited from $\mathrm{SiH}_{4}, \mathrm{SiH}_{2} \mathrm{Cl}_{2}$ and $\mathrm{H}_{2}$ at a substrate temperature of $210^{\circ} \mathrm{C}$, unless otherwise stated. The depositions were performed in a conventional three-chamber system with load-lock using DC plasma excitation. One sample and the solar cell were prepared using very high frequency (VHF) plasma excitation at $70 \mathrm{MHz}$ at otherwise identical deposition conditions. The hydrogen dilution ratio $\mathrm{H}_{2} /\left(\mathrm{SiH}_{4}+\mathrm{SiH}_{2} \mathrm{Cl}_{2}\right)$ was kept constant at a value of $\sim 35$. Pressure during deposition was 0.9 torr. No special precautions were taken concerning the state of the reactor, such as pre-baking to reduce out-gassing from the walls. After $\sim 30 \mathrm{~min}$. heating in the load-lock, the substrates were transferred to the deposition chamber, followed by deposition. The base pressure before deposition was $\sim 1 \cdot 10^{-6}$ torr.

$\sigma_{\mathrm{d}}$ and $\sigma_{\mathrm{ph}}$ were measured under vacuum using thermally evaporated $\mathrm{Al}$ contacts of $7.5 \mathrm{~mm}$ length and $0.5 \mathrm{~mm}$ spacing. The temperature-dependence of $\sigma_{\mathrm{d}}$ was used to determine $\mathrm{E}_{\text {act }}$. Photo-conductivity was measured using homogeneously absorbed light of $\lambda=650 \mathrm{~nm}$ wavelength and varying intensity; $\sigma_{\mathrm{ph}}$ values given in the text were obtained by extrapolation to a generation rate of $10^{21} \mathrm{~cm}^{-3} \mathrm{~s}^{-1}$. A pronounced peak in the ultraviolet reflection spectrum at $\sim 275 \mathrm{~nm}$ is a reliable indication for microcrystalline material ${ }^{14,15}$. We therefore measured reflection spectra between 200 and $400 \mathrm{~nm}$ and determined the height of the $275 \mathrm{~nm}$ peak as an indication of the crystallinity of the material. The optical absorption coefficient in the highenergy region was determined using UV/visible transmission spectra and following the procedure proposed by Swanepoel ${ }^{16}$. Sub-bandgap absorption spectra were measured using the constant photo-current method (CPM) on samples with the same contact geometry as for the conductivity measurements. The I-V curve of the solar cell was measured at $\sim 25^{\circ} \mathrm{C}$ using light of $100 \mathrm{~mW} / \mathrm{cm}^{2}$ intensity and a spectrum close to AM 1.5 . 


\section{Results}

$\mu$-Si:H deposited with $\mathrm{SiH}_{2} \mathrm{Cl}_{2}$

Varying the $\mathrm{SiH}_{2} \mathrm{Cl}_{2} /\left(\mathrm{SiH}_{2} \mathrm{Cl}_{2}+\mathrm{SiH}_{4}\right)$ ratio in the plasma between zero (pure $\mathrm{H}_{2}$-diluted $\mathrm{SiH}_{4}$ ) and one (pure $\mathrm{H}_{2}$-diluted $\mathrm{SiH}_{2} \mathrm{Cl}_{2}$ ) resulted in the dark-conductivity $\sigma_{\mathrm{d}}$, dark-conductivity activation energy $E_{a c t}$ and photo-conductivity $\sigma_{\mathrm{ph}}$ values of Figure 1 , for $\sim 500 \mathrm{~nm}$ thick films. The $\mu \mathrm{c}-\mathrm{Si}: \mathrm{H}$ sample deposited from pure $\mathrm{H}_{2}$ diluted $\mathrm{SiH}_{4}$ exhibits a high $\sigma_{\mathrm{d}}$ in excess of $10^{-3} \mathrm{~S} / \mathrm{cm}$. $\mathrm{E}_{\text {act }}$ is $<0.2 \mathrm{eV}$, reflecting high-level oxygen doping. Adding only a few percent of $\mathrm{SiH}_{2} \mathrm{Cl}_{2}$ reduces $\sigma_{\mathrm{d}}$ by over five orders of magnitude to $1.6 \cdot 10^{-8} \mathrm{~S} / \mathrm{cm}$, which is as low as the value obtained for $\mu \mathrm{c}-\mathrm{Si}: \mathrm{H}$ made by the microdoping or purifying techniques ${ }^{8,9}$. $\mathrm{E}_{\text {act }}$ is $0.62 \mathrm{eV}$. $\sigma_{\mathrm{d}}$ and $\mathrm{E}_{\text {act }}$ turn out to be very insensitive to the $\mathrm{SiH}_{2} \mathrm{Cl}_{2} /\left(\mathrm{SiH}_{2} \mathrm{Cl}_{2}+\mathrm{SiH}_{4}\right)$ ratio $\mathrm{R}$ in the gas phase over the wide range of mixtures $\mathrm{R}$ from 0.08 to 0.33 . For ratios $\mathrm{R} \geq 0.5$, the films grow amorphous (Figure 2) and exhibit $\sigma_{\mathrm{d}}$ values of $<10^{-12} \mathrm{~S} / \mathrm{cm}$ and $\mathrm{E}_{\text {act }}$ of $\sim 1 \mathrm{eV} . \sigma_{\mathrm{ph}}$ of the $\mu \mathrm{c}-\mathrm{Si}: \mathrm{H}$ film deposited at $\mathrm{R}=0.08$ is $2 \cdot 10^{-6} \mathrm{~S} / \mathrm{cm}$; for films deposited with higher amounts of $\mathrm{SiH}_{2} \mathrm{Cl}_{2}$, $\sigma_{\text {ph }}$ decreases gradually to $5 \cdot 10^{-7} \mathrm{~S} / \mathrm{cm}$ at $\mathrm{R}=0.33 . \mathrm{SiH}_{2} \mathrm{Cl}_{2}$ has the same effect on $\sigma_{\mathrm{d}}$ and $\mathrm{E}_{\text {act }}$ when using the VHF deposition technique, which has been found to be especially favorable to the deposition of $\mu \mathrm{c}-\mathrm{Si}: \mathrm{H}^{17}$. Values for the VHF-deposited sample at $\mathrm{R}=0.08$ are $\sigma_{\mathrm{d}}=5.4 \cdot 10^{-8} \mathrm{~S} / \mathrm{cm}, \mathrm{E}_{\mathrm{act}}=0.62 \mathrm{eV}$ and $\sigma_{\mathrm{ph}}=1.0 \cdot 10^{-5} \mathrm{~S} / \mathrm{cm}$, the latter being almost an order of magnitude higher than for the best DC-deposited sample.

The growth rate is influenced only slightly by the $\mathrm{SiH}_{2} \mathrm{Cl}_{2} /\left(\mathrm{SiH}_{2} \mathrm{Cl}_{2}+\mathrm{SiH}_{4}\right)$ ratio and is $\sim 1 \AA / \mathrm{s}$ for all samples shown in Figure 1 and Figure 2, which were grown at the power density of $\sim 100 \mathrm{~mW} / \mathrm{cm}^{2}$. Growth rates of $1.8 \AA / \mathrm{s}$ have been obtained by increasing the power density to 
$\sim 280 \mathrm{~mW} / \mathrm{cm}^{2}$. The growth rate for the VHF sample at a power density of $\sim 45 \mathrm{~mW} / \mathrm{cm}^{2}$ was $0.8 \AA / s$.

Figure 2 shows the height of the UV reflectance peak at $275 \mathrm{~nm}$, normalized to the peak height for crystalline silicon, as a function of the $\mathrm{SiH}_{2} \mathrm{Cl}_{2}$ fraction. A small amount of $\mathrm{SiH}_{2} \mathrm{Cl}_{2}$ in the plasma is seen to enhance the crystallinity of the film. Upon further increase in $\mathrm{SiH}_{2} \mathrm{Cl}_{2}$, the crystallinity decreases and eventually the material becomes amorphous at $\mathrm{R} \geq 0.5$. Raising the temperature enhances the crystallinity (Figure 2), while $\sigma_{\mathrm{d}}$ and $\mathrm{E}_{\mathrm{act}}$ remain at their intrinsic values of $\sim 10^{-8} \mathrm{~S} / \mathrm{cm}$ and $>0.6 \mathrm{eV}$, respectively. The crystallinity of the VHF-deposited sample is much higher than that of the equivalent DC sample, which explains the slightly higher $\sigma_{\mathrm{d}}$ at the same $\mathrm{E}_{\text {act }}$ compared to the DC-deposited sample.

Figure 3 shows optical absorption spectra obtained from UV/visible transmission and constant photocurrent method (CPM) spectroscopy. All samples were made at $\mathrm{R}=0.08$. Figure 3 features two $\sim 500 \mathrm{~nm}$ thick films which are deposited using DC excitation at $210^{\circ} \mathrm{C}$ and $280^{\circ} \mathrm{C}$ and a $\sim 750 \mathrm{~nm}$ thick VHF-deposited sample $\left(210^{\circ} \mathrm{C}\right)$. The absorption spectrum of crystalline silicon is shown for comparison. The sample deposited at the higher temperature has a higher absorption coefficient for red wavelengths. The absorption coefficient in the low-energy region $(\sim 0.8 \mathrm{eV})$ of the CPM spectrum is an indication of the defect density ${ }^{18-20}$. The absorption coefficient at $h v=0.8 \mathrm{eV}$ of the VHF-deposited sample is an order of magnitude lower than that of the DC-deposited sample. This indicates a lower defect density and correlates with $\sigma_{\mathrm{ph}}$, which is an order of magnitude higher for the VHF-deposited than for the DC-deposited sample. The CPM spectrum of the VHF-deposited sample is comparable to device-grade $\mu \mathrm{c}-\mathrm{Si}: \mathrm{H}$ deposited without $\mathrm{SiH}_{2} \mathrm{Cl}_{2}{ }^{20}$. 
Determining the optical bandgap as the intersection of the $\sqrt{\alpha(\mathrm{hv})}$ plot with the energy axis $^{20}$, we obtain a value of roughly $1.1 \mathrm{eV}$ for our $\mu \mathrm{c}-\mathrm{Si}: \mathrm{H}(: \mathrm{Cl})$ which is the same as the value for $\mu \mathrm{c}-\mathrm{Si}: \mathrm{H}$ deposited without $\mathrm{SiH}_{2} \mathrm{Cl}_{2}{ }^{20}$. An activation energy of $\sim 0.6 \mathrm{eV}$ means that the Fermi level lies close to midgap.

Figure 4 shows a cross-sectional SEM micrograph of the $\mu \mathrm{c}-\mathrm{Si}: \mathrm{H}(: \mathrm{Cl})$ film deposited at $\mathrm{R}=0.08$ and using VHF plasma excitation.

\section{Effect of chlorine on oxygen incorporation}

The presence of chlorine in the plasma reduces the oxygen content of $\mu \mathrm{c}-\mathrm{Si}: \mathrm{H}$. Figure 5 shows SIMS depth profiles ${ }^{21}$ for a sample consisting of three layers of $\mu \mathrm{c}-\mathrm{Si}: \mathrm{H}$ deposited with three different additions of $\mathrm{SiH}_{2} \mathrm{Cl}_{2}$. The top and bottom layers are a-Si:H encapsulating layers. Layer A was deposited using only $\mathrm{SiH}_{4}$ and $\mathrm{H}_{2}$. The oxygen content $\mathrm{c}_{\mathrm{O}}$ of this layer is as high as $8 \cdot 10^{19} \mathrm{~cm}^{-3}$, which explains its high $\sigma_{\mathrm{d}}$ of $4 \cdot 1 \cdot 10^{-3} \mathrm{~S} / \mathrm{cm}$ (Figure 1). Layer B was deposited with $\mathrm{R}=0.08$ at the same $\mathrm{H}_{2}$ dilution ratio. In this layer, $\mathrm{c}_{\mathrm{O}}$ is reduced by a factor of two to $\sim 4 \cdot 10^{19} \mathrm{~cm}^{-3}$. The chlorine content $\mathrm{c}_{\mathrm{Cl}}$ is $3-4 \cdot 10^{19} \mathrm{~cm}^{-3}$, which is nearly as high as $\mathrm{c}_{\mathrm{O}}$. For $\mathrm{R}=0.17$ (layer $\mathrm{C}$ ), $\mathrm{c}_{\mathrm{O}}$ decreases further to $3 \cdot 10^{19} \mathrm{~cm}^{-3}$ and $\mathrm{c}_{\mathrm{Cl}}$ increases to $6-7 \cdot 10^{19} \mathrm{~cm}^{-3}$. Chlorine in the plasma therefore reduces $c_{O}$ of the growing film whereas the growth rate is nearly unchanged. It is not clear whether the reduction of $\mathrm{c}_{O}$ can account for the intrinsic character of the films deposited with $\mathrm{SiH}_{2} \mathrm{Cl}_{2}$ or if other mechanisms take place, because $c_{\mathrm{O}}$ drops by a factor of two upon addition of $\mathrm{SiH}_{2} \mathrm{Cl}_{2}$ whereas $\sigma_{\mathrm{d}}$ drops by over 5 orders of magnitude.

Figure 6 shows $\mathrm{c}_{\mathrm{O}}$ and $\mathrm{c}_{\mathrm{Cl}}$ in our $\mu \mathrm{c}-\mathrm{Si}: \mathrm{H}$ for a larger set of samples. The addition of a small amount $(\mathrm{R}=0.08)$ of $\mathrm{SiH}_{2} \mathrm{Cl}_{2}$ to the plasma reduces $\mathrm{c}_{\mathrm{O}}$ by over a factor of two. Further additions of $\mathrm{SiH}_{2} \mathrm{Cl}_{2}$ has a smaller effect on $\mathrm{c}_{\mathrm{O}}$. $\mathrm{c}_{\mathrm{Cl}}$ increases with increasing amount of $\mathrm{SiH}_{2} \mathrm{Cl}_{2}$ in the 
plasma. Likewise, we show in Figure 1 that $\sigma_{\mathrm{d}}$ and $\mathrm{E}_{\mathrm{act}}$ of the $\mu \mathrm{c}-\mathrm{Si}: \mathrm{H}$ samples made with the smallest addition of $\mathrm{SiH}_{2} \mathrm{Cl}_{2}(\mathrm{R}=0.08)$ already correspond to those of intrinsic films.

Possible explanations for the intrinsic character of $\mu \mathrm{c}-\mathrm{Si}: \mathrm{H}(: \mathrm{Cl})$ are a) a threshold value of $\mathrm{c}_{\mathrm{O}}$ below which the doping effect of $\mathrm{O}$ is negligible, b) the p-type doping effect of $\mathrm{Cl}$ compensates the n-type doping of the $\mathrm{O}$, or c) $\mathrm{Cl}$ deactivates $\mathrm{O}$ as a dopant. Let us briefly discuss these alternatives.

a) $\mathrm{O}$ acting as a dopant only above a certain concentration does not seem to be a probable explanation. However, one could imagine that a certain amount of $\mathrm{O}$ can be incorporated into the material without creating free carriers and therefore without shifting the Fermi level.

b) $\mathrm{Cl}$ has indeed been found to be a slight p-type dopant in a-Si: $\mathrm{H}^{22,23}$. However, whereas $\mathrm{c}_{\mathrm{Cl}}$ and $\mathrm{c}_{\mathrm{O}}$ are on the same order of magnitude for films deposited with small amounts of $\mathrm{SiH}_{2} \mathrm{Cl}_{2}, \mathrm{c}_{\mathrm{Cl}}$ continues to increase with higher $\mathrm{SiH}_{2} \mathrm{Cl}_{2}$ ratios while $c_{\mathrm{O}}$ remains almost constant (Figure 6). $\sigma_{\mathrm{d}}$ would be expected to increase and $\mathrm{E}_{\mathrm{act}}$ to decrease with increasing $\mathrm{c}_{\mathrm{Cl}}$ if $\mathrm{Cl}$ were an efficient dopant.

c) One can imagine that $\mathrm{Cl}$ in the material could deactivate the doping effect of oxygen. The number of donors due to the presence of $\mathrm{O}$ could indeed be reduced if $\mathrm{Si}-\mathrm{O}-$ or $\mathrm{Si}-\mathrm{O}-\mathrm{H}$ bonds in "regular" $\mu \mathrm{c}-\mathrm{Si}: \mathrm{H}$ were replaced by much stronger $\mathrm{Si}-\mathrm{O}-\mathrm{Cl}$ bonds in $\mu \mathrm{c}-\mathrm{Si}: \mathrm{H}(: \mathrm{Cl})$. At this point it can, however, not be excluded that another reason accounts for the fact that the energetic distribution of defects in $\mu \mathrm{c}-\mathrm{Si}: \mathrm{H}: \mathrm{Cl}$ differs from that in "regular" $\mu \mathrm{c}-\mathrm{Si}: \mathrm{H}$. The energetic position and charge state of the defect states will determine the position of the Fermi level.

\section{Microcrystalline film growth and oxygen incorporation}

$\sigma_{\mathrm{d}}$ is plotted for a thickness series of $\mu \mathrm{c}-\mathrm{Si}: \mathrm{H}$ deposited with $\mathrm{R}=0.08$ in Figure 7 . For very thin films, $\sigma_{\mathrm{d}}$ corresponds to that of amorphous material. Note that $\sigma_{\mathrm{d}}$ of a-Si:H deposited with 
$\mathrm{SiH}_{2} \mathrm{Cl}_{2}$ is usually 1-2 orders of magnitude lower than that of a-Si:H deposited from pure $\mathrm{SiH}_{4}{ }^{24}$. Very thin samples are amorphous as the lack of a pronounced UV reflection peak confirms. $\sigma_{\mathrm{d}}$ and UV reflectance increase within the first $150-200 \mathrm{~nm}$ to the final value for bulk $\mu \mathrm{c}-\mathrm{Si}: \mathrm{H}$ films. Within approximately the same thickness range, i.e. $100-150 \mathrm{~nm}$, the SIMS hydrogen depth profile shows the transition from a-Si:H to $\mu \mathrm{c}-\mathrm{Si}: \mathrm{H}$ with a lower $\mathrm{H}$ content (Figure 7, bottom). Interestingly, $c_{O}$ also increases only gradually with increasing crystallinity, even though the gas mixture does not change and therefore the amount of $\mathrm{O}$ coming with the feedstock gases or from the chamber walls does not change either. We conclude therefore that the altered material structure of $\mu \mathrm{c}-\mathrm{Si}: \mathrm{H}$ compared to a-Si:H is the reason for the enhanced $\mathrm{O}$ incorporation. The time scale of the increase in the $c_{O}(\sim 25 \mathrm{~min}$ for $150 \mathrm{~nm}$ at $1 \AA / \mathrm{s})$ excludes as an explanation $\mathrm{O}$ entrained with the feedstock gases and accumulating gradually in the chamber during deposition.

\section{Solar cell}

We tested our $\mu \mathrm{c}-\mathrm{Si}: \mathrm{H}(: \mathrm{Cl})$ in a solar cell with p-i-n structure (Figure 8). The i-layer thickness is $1.8 \mu \mathrm{m}$, the substrate is textured $\mathrm{SnO}_{2}$ and the back contact is $\mathrm{Ag}$ which was thermally evaporated onto the n-layer, without a $\mathrm{ZnO}$ reflector layer in between. The solar cell shows a $\mathrm{V}_{\text {oc }}$ of $\sim 350 \mathrm{mV}$ and red response up to $\lambda=1000 \mathrm{~nm}$ (Figure 9). The fill factor is $55 \%$. Even though the short circuit current density value of $4.14 \mathrm{~mA} / \mathrm{cm}^{2}$ is low, the flat reverse-bias response suggests that the photo-carrier collection in forward bias is efficient. We believe that non-optimal optical performance (TCO haze, TCO reduction during deposition, lack of back reflector) cause the low photocurrent. 


\section{Conclusions}

In conclusion, intrinsic $\mu \mathrm{c}-\mathrm{Si}: \mathrm{H}$ can be deposited in a PECVD process when chlorine is present in the plasma. A dark-conductivity of $5.4 \cdot 10^{-8} \mathrm{~S} / \mathrm{cm}$, activation energy of $0.62 \mathrm{eV}$ and photoconductivity of $1.0 \cdot 10^{-5} \mathrm{~S} / \mathrm{cm}$ are obtained. The optical bandgap for this new material is approximately $1.1 \mathrm{eV}$. The deposition process does not require any gas purifying or microdoping procedures and is very insensitive to reactor conditions. A small amount of chlorine in the gas enhances the crystallinity of the material and reduces the amount of oxygen incorporated into the sample by over a factor of two. Sub-bandgap absorption spectroscopy indicates a low defect density in our material. VHF deposition yields material with lower defect density and higher photo-conductivity than material deposited using DC plasma excitation. Transition from amorphous to microcrystalline growth happens during the first $100-150 \mathrm{~nm}$ of film growth. The altered material structure of $\mu \mathrm{c}-\mathrm{Si}: \mathrm{H}$ compared to a-Si:H is the reason for the enhanced $\mathrm{O}$ incorporation as the oxygen content increases with increasing crystallinity during growth. A solar cell with a $1.8 \mu \mathrm{m}$ thick $\mu \mathrm{c}-\mathrm{Si}: \mathrm{H}(: \mathrm{Cl})$ i-layer exhibits $\mathrm{V}_{\mathrm{oc}}=0.35 \mathrm{~V}, \mathrm{I}_{\mathrm{sc}}=4.14 \mathrm{~mA} / \mathrm{cm}^{2}$ and $\mathrm{FF}=55 \%$, proving that the material is suitable for device fabrication.

\section{Acknowledgements}

R. Platz thanks the Arthur u. Aenne Feindt Stiftung, Hamburg (Germany), and the Fondation Charles-Edouard Guillaume, Bienne (Switzerland) for funding of his stay at Princeton University. The Electric Power Research Institute supported this research. 


\section{References}

${ }^{1}$ J. Meier, R. Flückiger, H. Keppner, A. Shah, Appl. Phys. Lett. 65 (1994) 860.

${ }^{2}$ J. Meier, S. Dubail, R. Flückiger, D. Fischer, H. Keppner, A. Shah, Proc. 1st WCPEC (1994) 409.

${ }^{3}$ J. Meier, S. Dubail, R. Platz, P. Torres, U. Kroll, J.A. Anna Selvan, N. Pellaton Vaucher, C. Hof, D. Fischer, H. Keppner, R. Flückiger, A. Shah, V. Shklover, K.-D. Ufert, Solar Energy Materials and Solar Cells 49 (1997) 35.

${ }^{4}$ T. Nagahara, K. Fujimoto, N. Kohno, Y. Kashiwagi, H. Kakinoki, Jpn. J. Appl. Phys. 31 (1992) 4555.

${ }^{5}$ S.S. He, G. Lucovsky, MRS Symp. Proc. 336 (1994) 25.

${ }^{6}$ M.W.D. Froggatt, W.I. Milne, M.J. Powell, MRS Symp. Proc. 467 (1997) 893.

${ }^{7}$ S. Veprek, Z. Iqbal, R.O. Kühne, P. Capezutto, F-A. Sarott, J.K. Gimzewski, J. Phys. C: Solid State Physics 16 (1983) 6241

${ }^{8}$ P. Torres, J. Meier, R. Flückiger, U. Kroll, J.A. Anna Selvan, H. Keppner, A. Shah, S.D. Littlewood, I.E. Kelly, P. Giannoulès, Appl. Phys. Lett. 69 (1996) 1373.

${ }^{9}$ R. Flückiger, J. Meier, M. Goetz and A. Shah, J. Appl. Phys. 77(2) (1995) 712.

${ }^{10}$ F. Wang, H.N. Liu, Y.L. He, A. Schweiger, R. Schwarz, J. Non-Cryst. Solids 137\&138 (1991) 511.

${ }^{11}$ Z. Iqbal, P. Capezzuto, M. Braun, H.R. Oswald, S. Veprek, G. Bruno, F. Cramarossa, H. Stüssi, J. Brunner, M. Schärli, Thin Solid Films 87 (1982) 43.

${ }^{12}$ H. Shirai, T. Arai and T. Nakamura, Techn. Dig. PVSEC-9 (1996) 853.

${ }^{13}$ S.K. Kim, B.Y. Moon, J.S. Byun, H.B. Jeon and J. Jang, Appl. Phys. Lett. 69 (1996) 1131. 
${ }^{14}$ A.H. Jayatissa, Y. Nakanishi, Y. Hatanaka, Jpn. J. Appl. Phys. 32 (1993) 3729.

${ }^{15}$ T.I. Kamins, Polycrystalline silicon for integrated circuit applications, Kluwer Academic Publishers 1988, p.68.

${ }^{16}$ R. Swanepoel, J. Sci. Instr. 16 (1983) 1214.

${ }^{17}$ F. Finger, P. Hapke, M. Luysberg, R. Carius, H. Wagner, M. Scheib, Appl. Phys. Lett. 65 (1994) 2558.

${ }^{18}$ W.B. Jackson, N.M. Johnson, D.K. Biegelsen, Appl. Phys. Lett. 43 (1983) 195.

${ }^{19}$ Z. Iqbal, F.A. Sarott, S. Veprek, J. Phys. C: Appl. Phys. 16 (1983) 2005.

${ }^{20}$ N. Beck, J. Meier, J. Fric, Z. Remes, A. Poruba, R. Flückiger, J. Pohl, A. Shah, M. Vanecek, J. Non-Cryst. Solids 198-200 (1996) 903.

${ }^{21}$ SIMS measurements performed by Evans East, Plainsboro, NJ 08536.

${ }^{22}$ A.E. Delahoy, R.W. Griffith, J. Appl. Phys. 52 (1981) 6337.

${ }^{23}$ K.S. Lee, J.H. Choi, S.K. Kim, H.B. Jeon, J. Jang, Appl. Phys. Lett. 69 (1996) 2403.

${ }^{24}$ A.M. Payne, B.K. Crone, S. Wagner, MRS Symp. Proc. 467 (1997) 789. 


\section{Figures}

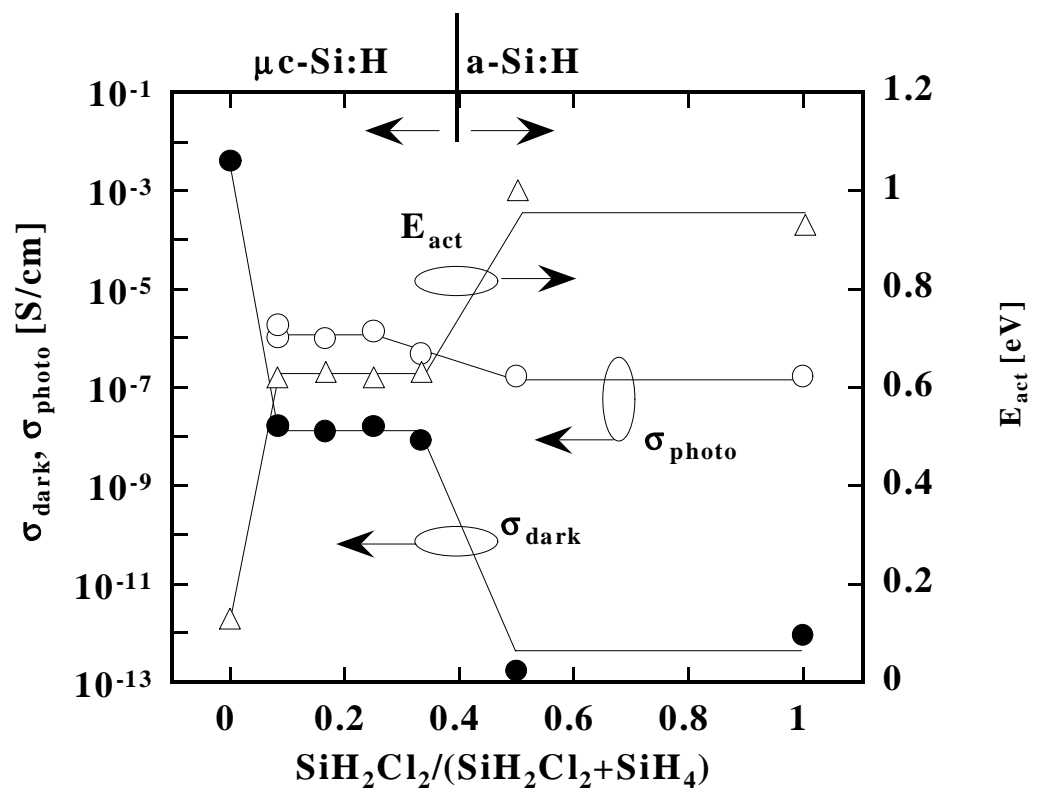

Figure 1 


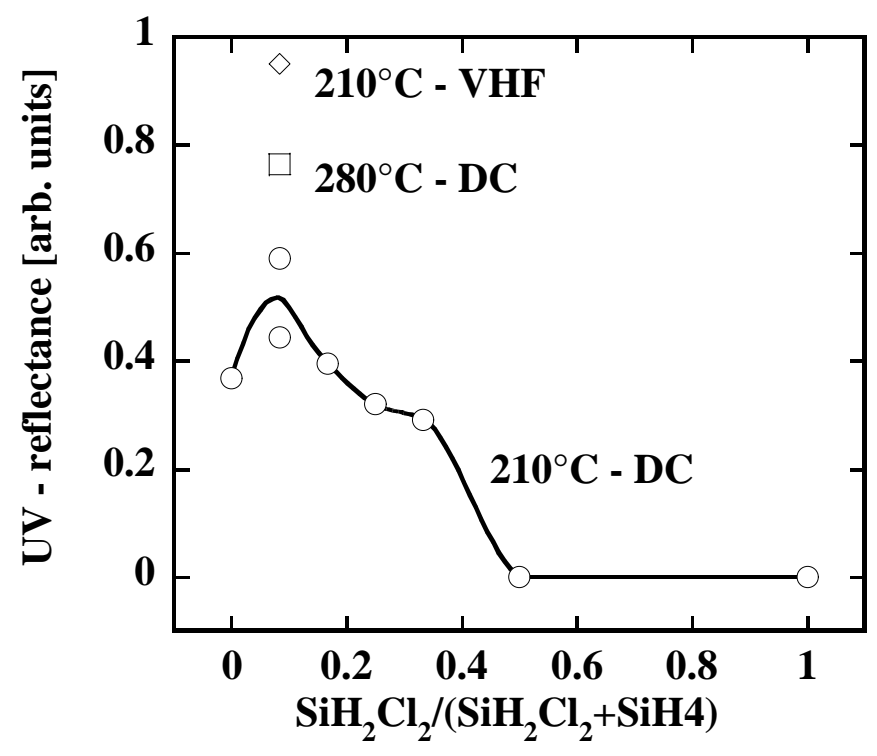

Figure 2 


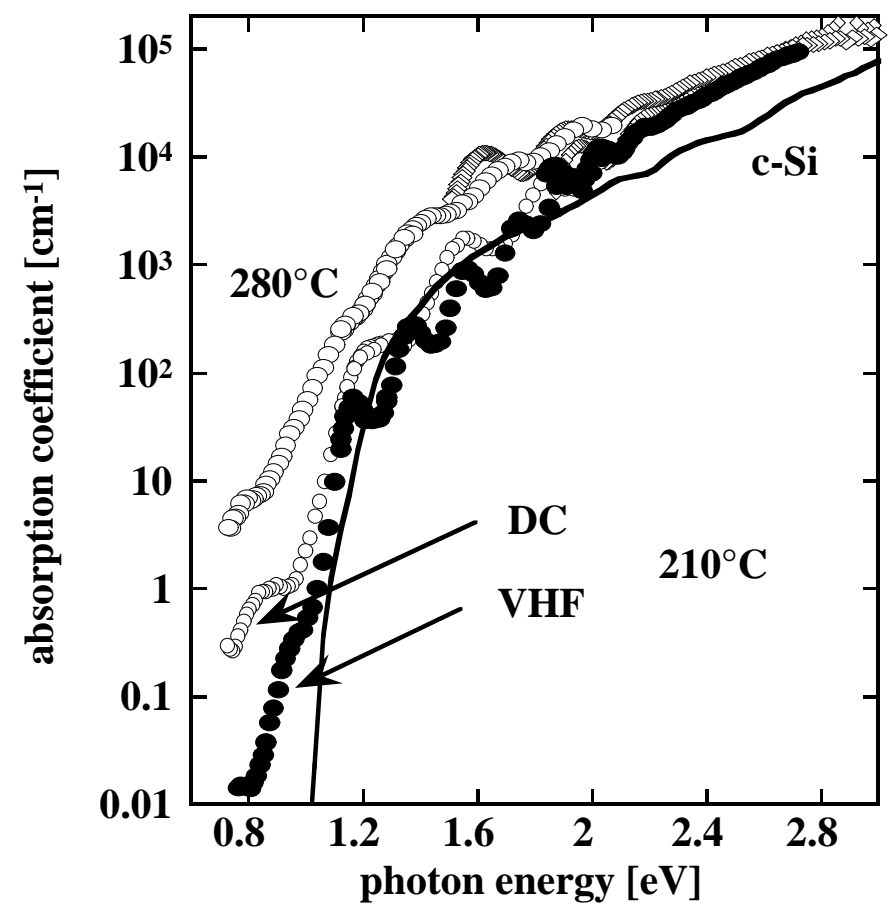

Figure 3 


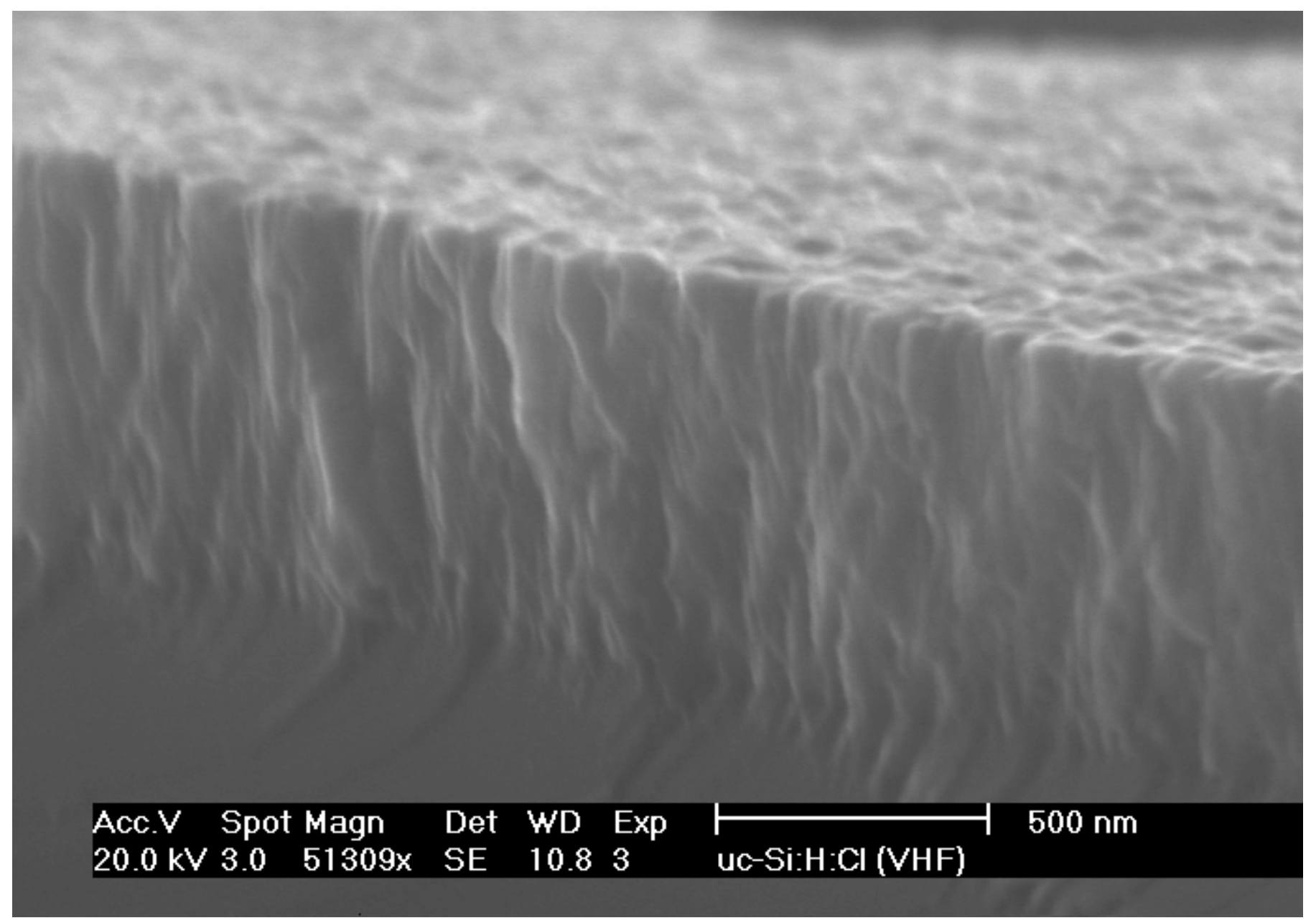

Figure 4 


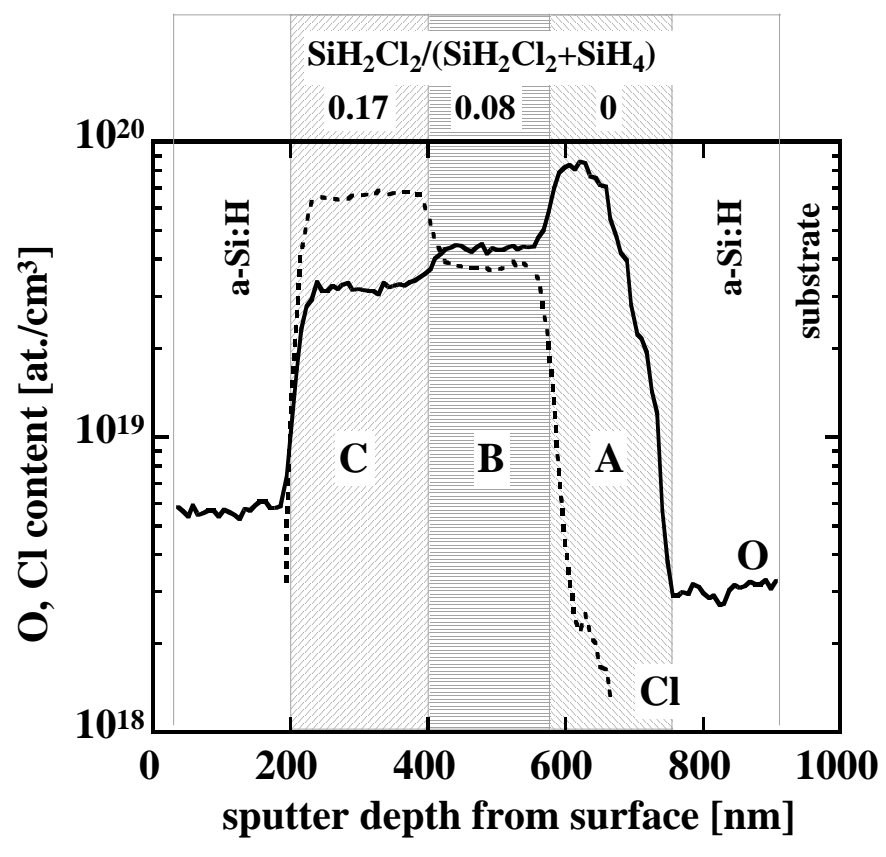

Figure 5 


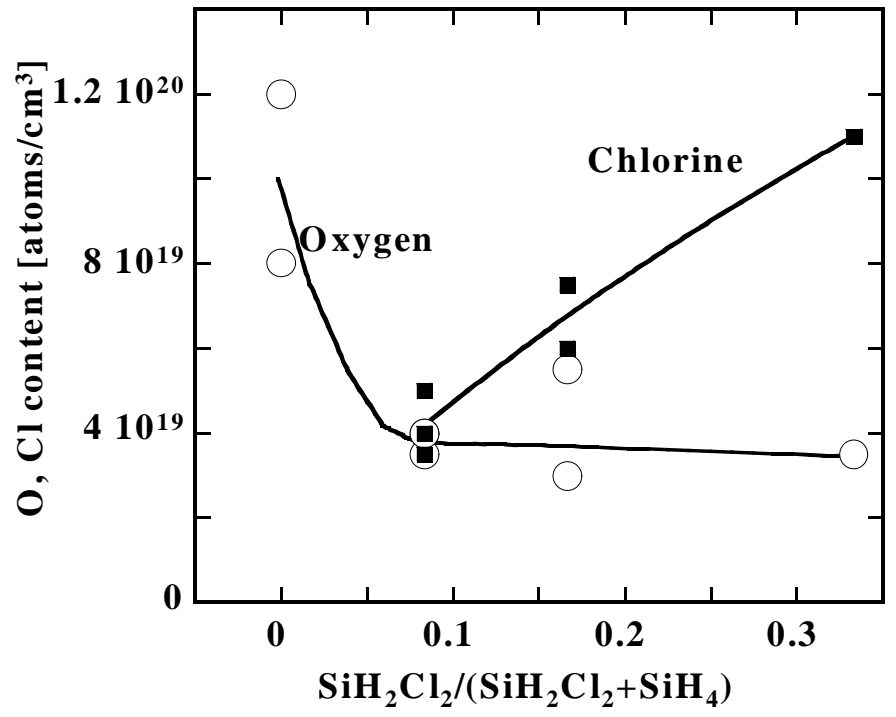

Figure 6 


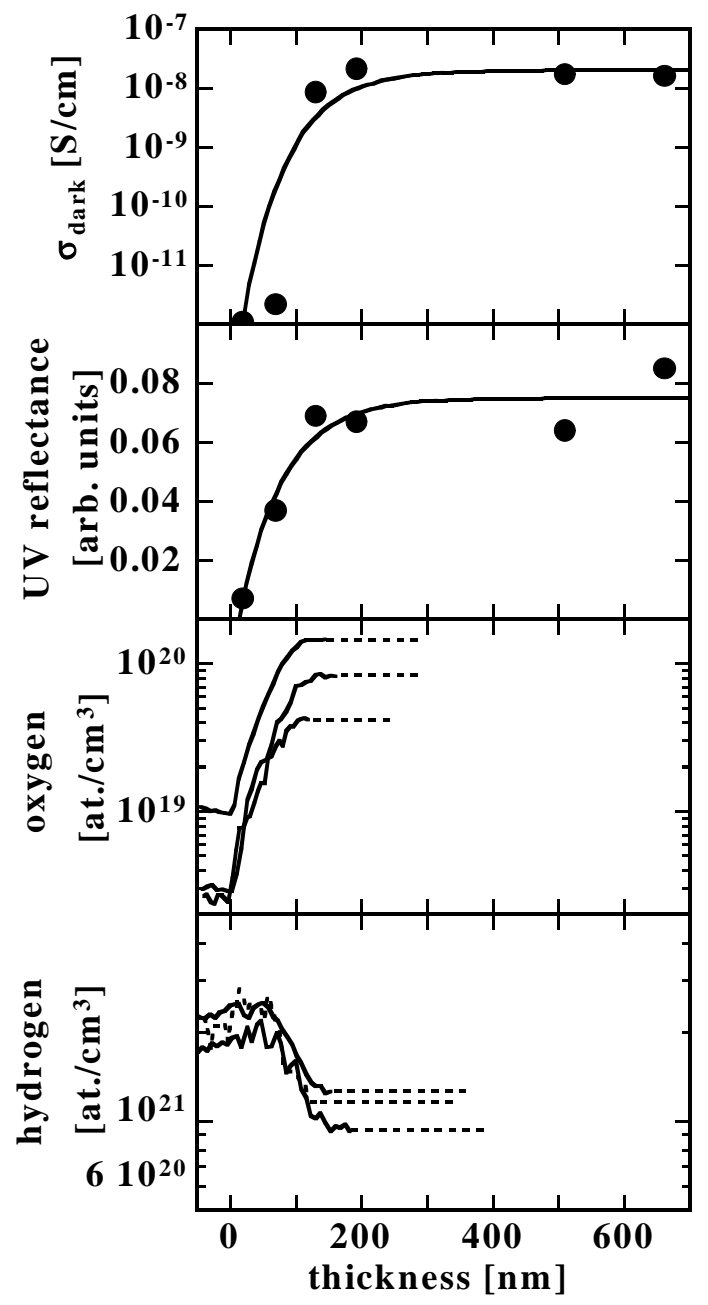

Figure 7 


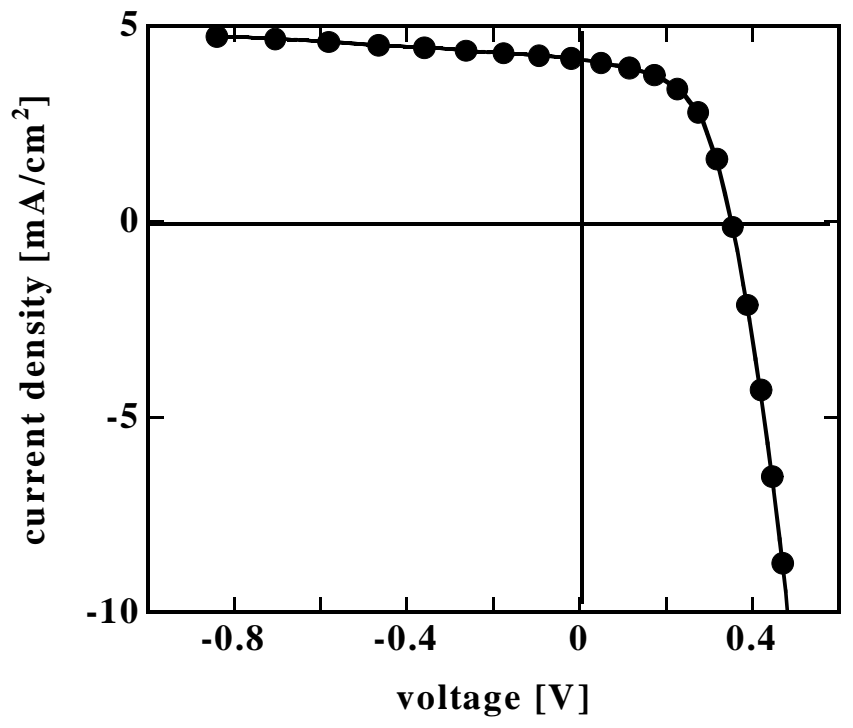

Figure 8 


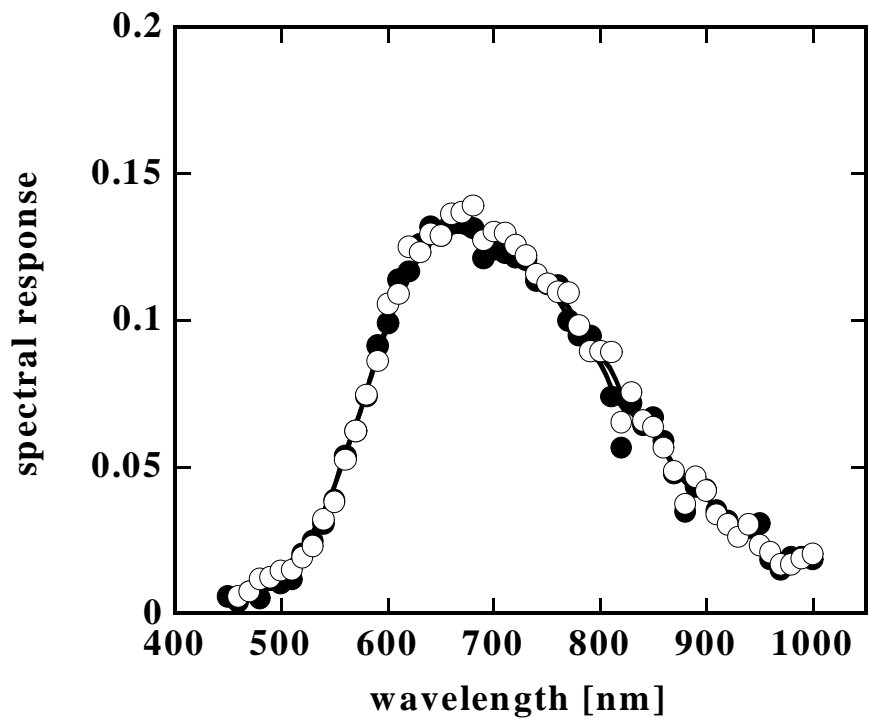

Figure 9 


\section{Figure captions}

Figure 1: Dark-conductivity, dark-conductivity activation energy and photo-conductivity as functions of the amount of $\mathrm{SiH}_{2} \mathrm{Cl}_{2}$ in the gas phase for DC-deposited samples.

Figure 2: Ultraviolet reflectance at $\lambda=275 \mathrm{~nm}$ normalized to crystalline silicon.

Figure 3: Optical absorption spectra measured by constant photocurrent method (CPM) and UV/visible transmission spectroscopy for two substrate temperatures. Crystalline silicon is shown for comparison.

Figure 4: Cross-sectional SEM micrograph of a VHF-deposited $\mu \mathrm{c}-\mathrm{Si}: \mathrm{H}(: \mathrm{Cl})$ film on crystalline silicon substrate. $\mathrm{SiH}_{2} \mathrm{Cl}_{2}$ fraction is $\mathrm{R}=0.08$.

Figure 5: Oxygen and chlorine SIMS depth profile for $\mu \mathrm{c}-\mathrm{Si}: \mathrm{H}$ deposited on a-Si:H and capped with a-Si:H. The $\mu$ c-Si:H layers were deposited with $\mathrm{SiH}_{2} \mathrm{Cl}_{2} /\left(\mathrm{SiH}_{2} \mathrm{Cl}_{2}+\mathrm{SiH}_{4}\right)$ ratios of 0 (layer A), 0.08 (B), and 0.17 (C). Note the opposite trends in $\mathrm{Cl}$ and $\mathrm{O}$ concentrations. All layers are deposited using DC plasma excitation.

Figure 6: Oxygen and chlorine content in our $\mu \mathrm{c}-\mathrm{Si}: \mathrm{H}$ as a function of the $\mathrm{SiH}_{2} \mathrm{Cl}_{2}$ ratio. All layers are deposited using DC plasma excitation.

Figure 7: Top: dark-conductivity and UV reflectance for a thickness series of $\mu \mathrm{c}-\mathrm{Si}: \mathrm{H}$ deposited with a $\mathrm{SiH}_{2} \mathrm{Cl}_{2} /\left(\mathrm{SiH}_{2} \mathrm{Cl}_{2}+\mathrm{SiH}_{4}\right)$ ratio of 0.08 in a DC-excited plasma. Bottom: oxygen and hydrogen depth profiles from SIMS for $\mu \mathrm{c}-\mathrm{Si}: \mathrm{H}$ samples deposited with and without $\mathrm{SiH}_{2} \mathrm{Cl}_{2}$ in the plasma. The figure shows the transition from amorphous to microcrystalline silicon within the first $150 \mathrm{~nm}$ of growth. This transition and the increase in the oxygen content occur simultaneously. 
Figure 8: I-V curve of a p-i-n solar cell with an i-layer of $1.8 \mu \mathrm{m}$ thick $\mu \mathrm{c}-\mathrm{Si}: \mathrm{H}(: \mathrm{Cl})$ deposited by VHF.

Figure 9: Spectral response of the solar cell of Figure 8 measured at $0 \mathrm{~V}$ ( $\mathrm{I}_{\mathrm{sc}}$ conditions, black symbols) and $-2 \mathrm{~V}$ (open symbols) bias. 